\title{
From Legal Translation to Legal Globalization: Globalization of Criminal Laws to Counter Global Crimes
}

\author{
Morad Yasin Deab Al-Refo and Raed S. A. Faqir
}

\begin{abstract}
It is the responsibility of national state to enact and implement its national criminal legislations on all types of crimes that occur within its political borders, in accordance with its own social circumstances and economic interests. On the same context, no other state is allowed to interfere with such powers and authorities. As one of the aspects of national sovereignty, the criminal law still based on the doctrine of "territorial basis" that despite saying it has been developed, but not more than crimes. At the age of globalization, national traditional criminal laws suffer from inefficiency in dealing with the new types of crimes, such as financial offences, hi-tech crimes and information systems crimes as well as computer related crimes.

The information and communication revaluation, liberation of international trade and removing the political borders of national states all were the result of globalization, which facilitated not only the movement of capitals, ideas, goods, but also destructive materials, such as drugs, atomic weapons, and chemical Products and International adulterated and toxic industrial wastes, by which crimes became global phenomena.
\end{abstract}

Index Terms - Legal translation, globalization of criminal law, international crimes, language.

\section{INTRODUCTION}

The present paper focuses on the both legal literature and translation as actual machinery for globalizing the criminal law. This paper explains the multidimensional factors and aspects of the globalization of criminal law outlining those aspects and changes in the criminal law at both national and international levels. The paper further discusses the relationship between globalization and major developments of international law, especially the criminal law. The discussion proceeds by defining the terms of globalization and globalization of law, stating the relationship between legal translation and globalization, as well as the comparative law and its language. It shows also the globalization from legal literature perspective, and highlights issues related with globalization of criminal law, as well as the criminal penalties in the age of globalization.

The present paper tries to explain the impact of globalization on both the criminality and criminal legislation at both national and international levels, with taking into consideration role of legal translation in making the language of global criminal legislation more effective for combating the global criminality than it can be made by national laws.

Manuscript received October 6, 2014; revised December 25, 2014

Morad Yasin Deab Al-Refo is with the Translation, Umm Al-Qura University, the University College of Alqunfedah, the Kingdom of Saudi Arabia (e-mail: muradtt777@yahoo.com).

Raed S. A. Faqir is with the Balqa Applied University, Zarqa University Collage, Jordan (e-mail: fageerjo@yahoo.com).
The gab between so called the globalization of economy and globalization of legal norms may be reduced by using the tool of legal translation as to produce some criminal principles, doctrines and provisions applicable at all states of the glob, because it is well understood that the national borders of stated should not be opened only for the movements of economic interests, but also for the interests of criminal justice at global and local levels, otherwise the world my collapse with the increment of global crimes.

Before looking at the matters to be redressed and discussed, this paper attempts to present the legal mechanism for combating the global crimes and criminality by relying on the globalization of criminal law. This done for two reason: (1) to provide readers a clear perspective about the positive impacts of globalization especially on the criminal law and international cooperation for compacting global crimes (ii) to link different issues related to legal literature and translation with the idea of globalizing criminal law and shifting from local remedies for crimes to international solutions. The second part of this paper discusses the legal and linguistic perspectives of the globalization's terminology. The third part outlines those issues related to legal literature and translation linked with globalization of law. The fourth part is ascribed to main issue of globalization of law, which leads us to the notion of internationalizing the criminal law of national states. The fifth part redresses the issue of criminal penalties in the age of globalization. The conclusion follows thereafter.

\section{Terminology OF GLOBALIZATION: LEGAL AND LINGUSTICT PROSPECTIVES}

\section{A. Definition of Globalization}

Globalization is a term in heavy current usage but one whose meaning remains obscure, often even among those who invoke it. The verb 'globalize' appeared in the 1940s, together with the word 'globalize'. 'Globalization' first entered a dictionary (of American English) in 1961[1].

This concept can be defined as a global process, a concept, a revolution, and "an establishment of the global market free from sociopolitical control [2]. It is defined by Cerny as "a set of economic and political structures and processes deriving from the changing character of the goods and assets that comprise the base of the international political economy in particular, the increasing structural differentiation of those goods and assets" [3].

\section{B. Definition of Globalization of Law}

Globalization of law" is defined as "the worldwide progression of transnational legal structures and discourses along the dimensions of extensity, intensity, velocity and 
impact" [4]. From legal point, the concept of globalization of the law is, after all, an issue that embodies various things to several types of people. Geoffrey Samuel defines this term as "law operating at a supranational level", he explains the term more comprehensively by stating that "such as world trade and international arbitration; and there are a number of transnational codes, such as those for airline passengers and the principles of contract law" [5].

On the same context, the term of global law means "the setting up of the Institute acknowledges the impact of law across national boundaries and the need to deepen inquiry into comparative approaches to law and legal study." [6] Global law means also that "the law and its practice in a global environment", or "a multicultural, multinational, and multidisciplinary legal phenomenon finding its roots in international and comparative law and emerging through the international legal practice that was prompted by the globalization of the world economy" [6].

\section{Legal Translation and Globalization}

Legal translation is a very important topic in the era of globalization; it aims to make national legal systems more connected with the international standard, by enhancing the translation of all lexical items by promoting the use of "cross-examination" by translation of legal terms from one language to another. Therefore, legal translation may play a vital role in globalizing local laws on the way that relied on the use of "legal terms" and "technical terms and words" [7].

The translation of legal texts of any kind, from statute laws to contracts to courtroom testimony, is a practice that stands at the crossroads of legal theory, language theory and translation theory. It has been advocated that "the demand for legal translation is on the increase around the world owing to globalization and the increased contact and exchange between peoples and states" [8].

\section{Comparative Law and Its Language}

In general, there are two major types of law, the national law which is enacted within the limits of each national state, and the international law that has its impact on global levels of the entire countries. The first law regulates relations between individuals and national state with its citizens and subjects, as well as it is designed on the way that reflects national values and cultures of specific countries, while the second regulates relations between states, states and individuals as well as relations between international organizations and it is characterized with global nature and features [9].

The question here is that whether there is deference between international law and nation law? The answer is positive, in sense there are lot differences between both types of law [10]. The sources of international law are not the same for national law, as it takes its sources from conventions, treaties, customary laws and legal principles, in contrary the sources of national law are derived from the real social, economic and political developments and conditions, legislation, customs, jurisprudence, principles of justice...etc

Both international law and national law are different for many reasons; the subjects of the international law are states and organizations, while the subjects of national law are individuals. The object of both laws are different, the international law regulates relations between state in the times of peace and war, while the national law regulates relations of the state's individuals, as well as the structure of both types of laws are also different, in sense the national law managed by the three powers of the state, executive, legislative and judicial branches that represent a guarantee for it implementation, while in the international law case, those powers are not existed [10].

Among other six languages which are recognized within United Nations Organization is Arabic language, but still the English language is considered as the official language of the world. Most of the international treaties, conventions and documents are written in English and then translated to other languages including Arabic.

\section{E. Reception of Law}

Reception of law means that indigenous rules of the legal systems are transferred from other languages, for many reasons such as less experience of the received legal system, political and social dominance, or in other cases the students and graduates of law bring the values, concepts and some times provisions used in the legal system of the country of their study [11].

The problem of reception of law are related to the ways of copying, browning or translating of foreign laws, which may not fit the cultural and social variety of the two legal systems [11]. For example most of Arab countries, especially Jordan and Syria have browed the legal provisions of its criminal laws or punishments laws from French criminal legal system despite the variety of cultural, social and ideological aspects of the people in those countries [12]. Moreover, the provisions of any law, as laws are always the sprit of society, are designed to solve local and national social, economic, political and other sort of problems within specific periods of history [12]. Hence, the French criminal legal system that barrowed by the late of eighteenth century is applied till now in some of Arab countries with slight amendments.

\section{Globalization From Legal Literature PERSPECTIVE}

\section{A. Legal Literature and Globalization}

Globalization is an ethical issued issue based on an impartial idea that deals with human beings as living and dynamic elements. For this reason, fair globalization is based on ethical, but not contractual defense.

In the moral context, the main aim of human existence is the performance of one's duties oneself, and others and humanity as a whole, and the natural environment and ecosystem. In the legal literature, it is believed that humanism is founded on global ethical doctrines, which includes privileged dealing with others [13]. Hence, this term embodies egoism and egotism, reasons and emotions, responsibility and irresponsibility, rights and duties. It is a humanism that is not in harmony with the present situation of humankind: thus, it is useful to know much about the two principle ideas of Aristotle: be happy (to know oneself) and lead a dignified life. This means that the ethics of 
globalization must be outside the framework of utilitarian, the encouragement of individualism leads to unhappiness, while altruism leads to not merely the individual interest and happiness, but for benefit of all mankind [14].

\section{B. Law and Globalization Literature}

In the context of globalization literature, it is found that there are many writers shove apparent of most of the ambushes implicated in overdo and maltreatment of the term of globalization," and similar jargons. On the other hand, other writers tend investigate the globe in terms of tidily coated, fundamentally concentric models. In this stream, Domingo, for example, talks slackly of upright and horizontal levels of governance and of moving from the national to the international [15].

Domingo uses an analogy with geology to show his entire view about human connections and the doctrine of subsidiary: "A basic geological principle of original horizontality, according to which layers of rock are first deposited horizontally in an arrangement that remains fixed so long as no other force acts upon it. This same principle can be applied to the law because humanity also comprises different levels: personal, familial, local, regional, national, continental, and global. We must maintain this distribution, limiting as much as possible the use of force on its layers [16]

This is most likely excessively easy as geology; it is fairly confusing in esteem of law. The legacy of phenomena legal-related issues is much messier than that. Some of the most important prototypes concerning law are sub-global: the language spread, trading blocs, diasporas, legacies of empires, alliances, criminal networks, legal traditions and so on. Reflect on, for instance, the Islamic umma, the French empire, Al Qaeda, etc [15].

The sub-global terms are mostly interacting, interrelated, crisscrossing and diffusing in very complicated manners. Significantly, all these cases are somehow sub-global jargons. In history, it was not proved the existence of the global empire, a global common language, a solely world legal system, or even a really world war. The socio-political, various identities, and hybrid ethnicities are closely connected to such uncontrollable and vague models. An effort to design effective universal and transnational establishments must certainly be established in a sense of the past and on information without neglecting the reality of such complexities. From this reason, writers adopting and advocating Domingo's approach of "new pyramid of law" look rather too neat [15].

\section{Globalization, International Law and Human Rights}

Globalization is not linked only with economy, but it also plays vital role in inspiring the international law and global justice. the movement of changes and developments in international law are attributed to this phenomena, such as the establishment of United Nations, development of war laws, new rules for human rights respect, and establishment of preeminent international Criminal Court...etc.

Globalization of international law had started long time ago, it can be traced back to the period of Peace Treaties of Westphalia of 1648 , by which the old doctrines of international law replaced with new concepts [17]. This phenomenon introduced in new concepts of international law and international relations, those were new concept of sovereignty, non intervention with internal affair of states, rules of consent, international cooperation and international legitimacy [18]. Moreover, globalization made some sort of a systematic change to the rules of political order that change the role of states in both national and international levels.

The old regime of sovereignty has been changed by introducing interstate law, equal treatment for all states irrespective of its political forms, bridging united principles of international and national affairs, and the delegitimation any actions against the recognized national boarders.

\section{Globalization OF CRIMINAl LAW}

\section{A. Nationalization of Criminal Law}

It is the responsibility of national state to enact and implement its national criminal legislations on all types of crimes that occur within its political borders, in accordance with its own social circumstances and economic interests. On the same context, no other state is allowed to interfere with such powers and authorities. As one of the aspects of national sovereignty, the criminal law still based on the doctrine of "territory" that despite saying it has been developed, but not more than crimes.

At the age of globalization, national traditional criminal laws suffers from inefficiency in dealing with the new types of crimes, such as financial offences and hi-tech crimes and information systems crimes as well as computer related crimes

\section{B. Globalization of Criminal Law}

The most challenge faced by humanity in the present days is to guarantee that the phenomena of globalization should have its positive impact on the entire world's people, in lieu of leaving billions of them behind in nastiness. This phenomenon gains the focus of the laymen oversees, as it intervenes with the micro daily-life details of the world's people in levels of social, economic, legal, media and international relation, an cultural life of nations.

Globalization is a new multi-dimensional mechanism affecting every thing in the physical and virtual spaces of the globe; it has been viewed as a threat to humanity by saying that "We were sleeping on the shore when a big wave came", and it has been described negatively as "There is a growing feeling that we live in a world highly vulnerable to changes we cannot control; a growing sense of fragility among ordinary people, countries and entire regions", because of its serious impacts on the core of social building tools, for this reason it has been rightly stated that globalization may be viewed as a "threatening traditional institutions such as the family and the school"[19].

Most of scientific and legal research dealt with the phenomena of globalization and its relationship with state in general, while the topic of globalization and its relationship with criminal policy concerning state sovereignty and the role of states in the protection its citizens and their properties is rarely researched. The question here, what are the impacts of globalization on criminal legislation? And whether such 
impact reproduced a new international criminal polices? What is the scope of the globalization's impact on national criminal policies at the same time?

\section{Crimes and Globalization}

Crime can be defined as "an intentional act in violation of the criminal law committed without defense or excuse, and penalized by the state as a felony or misdemeanor" [20]. It is defined also as "An act for bidden by law and for performing which the perpetrator is liable to punishment".

The criminalization of any act is made as per certain slanders concerning the protection of rights, where such rights need some protection that varies from one to another as the degree of needs. in fact, there are rights that can be safeguarded with either civil or administrative protection, while other rights which are important for both society and individuals gain more legal protection by criminal laws. Hence, the evaluation of the importance of social interest behind the protection of right itself differs from one society to another as the verity of social customs, cultures and interest among nation [21].

This leads us to the fact of the relativity of the concept of "crime" and "offender", which means the determination of the criminalizing nature of the act differs from one society to another as per the importance of the social and moral interests violated by such act [22].

It is noted here, the crime of adultery in the Muslim world interpreted in a different way depending on the composition of the moral, social, ideological and religious prevailing in Muslim societies, which inevitably differ with him in the open Western societies, as some of these countries don't criminalize the act of infidelity. Here, the fear of the negative consequences of globalization on the culture of local communities in the states, Globalization change occur on the pyramid of values, which is the true measure for estimating the extent of the need to protect the interest or right, which is different in the East and West. In the era of globalization, the overseas corporations even intervene in the enactment of the criminal laws of the States, which leads to replacing the legal protection of nation's interests with overseas firm's interests [23].

\section{Globalization and New Types of Criminality}

German jurist Savigny says that the law is the spirit of community, which means that the provisions of the law must meet the needs of the community and address its problems. The change in the norms and customs of the peoples lead to changed needs and problems. The multinational companies play various roles in creating international business ethical rules and regulations through pressurizing sates in order to bring changes in its legal systems and legislation for more economic interests [24].

As for the nature of the crime itself, the phenomenon of globalization has reflected its impact in the field of organized crimes and made crimes with extra serious nature. Consequently, as extraordinary openness in trade, finance, travel and communication has created economic growth and well-being, it has also given rise to huge chances for criminals to make their business prosper. The new types of crimes are well organized and the criminals use the latest developed techniques to commit it, such as computers, network systems, information systems, internet and technology of communications [25].

The character of crime has revolutionized considerably in a single generation. Just decades ago, crime was organized in a hierarchy of operations. It was "industrial" in that it included the division of labor and the specialization of operations. This composition extended worldwide, as organized crime emulated the global business [26]. Globalization has not only changed the nature of crimes, but also changed its types and forms, the nature of criminal and victims and venue. Moreover, the means of modern crimes in the age of globalization became more developed than before, and the national legislation is paralyzed in dealing with those types of crimes. According to Findlay, the globalization of the market has introduced more and new forms of opportunity for criminals. Andrea Di Nicola and Alessandro Scartezzini say that "globalization has given those interested in fraud, for instance, the opportunity to act on an international level by taking advantage of the lack of regulations in the commercial and financial markets of some countries" [27].

The phenomenon of crime has globally expanded due to globalization, which create a legal crisis that need to be addressed. This crisis has made the credibility and effectiveness of the law in an awkward position, which requires concerted efforts not only on the legal level, but the economic and even moral to mitigate the negative aspects of globalization. it has been proven that a crime can be considered as globally problematic issue, especially when it occurs across frontiers, needs no actors and has an accentuating nature all over global nations [28].

The deficit in finding solutions that equal and commensurate with the challenges of globalization makes criminal law loses its primary function in the protection of both the society and individuals. Prior to globalization crimes are usually committed by desperate, marginalized and poor people, while now those crimes are increasingly committed by well educated persons for the same purposes of gaining financial benefit or for revenge ...etc

The new types of criminality are described by the American legal scholar Sutherland as "crimes of powerful persons", he says that such crimes are committed by the respectable and powerful persons, such as white collar crimes [29]. Opportunities for new crimes are created by demographic change, economic reform, globalization and technological advancement, but because of globalization "criminals have taken advantage of transitioning and more open economies to establish front companies and quasi-legitimate businesses that facilitate smuggling, money laundering, financial fraud, intellectual property piracy, and other illicit ventures" [30].

\section{CRiminal Penalties in the Age of Globalization}

\section{A. Global Nature of Criminal Law}

Globalization phenomenon targets the system of values in society, including the social values which are inherent source 
of punishment. Accordingly, the punishment was affected directly by this phenomenon due to the change of social values. In addition to the internationalization of human rights without taking into account the specificity of civilized societies led to a change in the system of punishment and criminal policy in the states. For this, pressure groups of the global human rights organizations led to abolish of some the deterrent penalties in many countries, and its example of the death penalty.

Globalization imposed many restrictions on the territorial principle, by which criminal law applies not only to the crime that was committed in whole or in part on the territory of the State, but also extends to crimes committed outside the territory of the State. It has been rightly stated that the global law is "more hybrid in nature, taking into account domestic laws of different countries and aiming to understand domestic regimes within the broader context of international laws, instruments and institutions", and the international criminal justice system may be, in this sense, considered as legal hybrid which is already originate from uniform body of different laws of both civil and common law systems [31].

\section{B. Nature of Global Crime}

It has been rightly stated that the crime can be considered as a global crime if it meets any one of the two criteria [28]: i) if a particular crime has an accentuating character in most nations on the globe. This crime does not necessarily need to have actors inducing it across frontiers or ii) the crime is occurring across frontiers and there are social actors inducing who traverse frontiers [32]. For example, organized crime is crime committed by criminal organizations, international jihad groups, street gangs, criminal groups, mafia organizations and terrorist groups. It should be noted that crimes are committed for an array of reasons, which include economic, physical, sexual, psychological, physical, social, and even political motivations. In the context of organized crime, financial incentives clearly play an important role in the person's decision to engage in crime. For this reason it can be said that the following crimes may be considered as global offences [33]:

- Dealing In illicit drugs

- Illegal trafficking in weapons

- Illegal trafficking in human beings

- Money Laundering

- Corruption

- Violent Crimes including terrorism

- War crimes

It is known that there is a clear link between the crime and the changes and global variables «globalization». Globalization affects states in its economic and political and security perspectives. Crimes, generally, in the age of globalization have been developed and those crimes, such as terrorism and intolerance, threat not only the state's security and social peace, but also the regional and global peace. The organized crime and corruption in various forms and genres are forms of the crimes in the contemporary context of globalization, which has benefited in terms of the type and form and content of the high technology in the means of technology, information and communication and increasing overlap between contemporary societies and the melting of the differences. The most prominent forms and images of crime and contemporary problems in the light of globalization, which is expected to increase with the increase in the prevalence of the concept of globalization caused removal and pros, as follows [34]:

- Terrorism.

- The drug trade.

- White slave trade and the sale of organs.

- Money laundering.

- Administrative corruption.

- Tax evasion.

- Increase the gap between rich and poor.

\section{Universal Crimes}

This term has been finally developed by the international law, as international crimes. Those crimes are punishable by the International Criminal Court. Article 5 of the Rome Statute criminalizes four acts as international crimes, including genocide, crimes against humanity, war crimes, and the crime of aggression. Those crimes "shall not be subject to any statute of limitations" [35].

Article 5 of the Rome Statute provides that 1) the jurisdiction of the Court shall be limited to the most serious crimes of concern to the international community as a whole. The Court has jurisdiction in accordance with this Statute with respect to the following crimes:

- The crime of genocide;

- Crimes against humanity;

- War crimes;

- The crime of aggression.

While paragraph 2) of the same Statute provides that the Court shall exercise jurisdiction over the crime of aggression once a provision is adopted in accordance with articles 121 and 123 defining the crime and setting out the conditions under which the Court shall exercise jurisdiction with respect to this crime. Such a provision shall be consistent with the relevant provisions of the Charter of the United Nations.

\section{CONCLUSION}

In this research, we have shown how, in the age of globalization, the translation as a vital tool of globalization tries to make common legal rules applied all over the world. This phenomenon made new applicable rules for both legal systems of civil law and common law, especially in term of legal procedures for compacting all types of the organized crimes.

As a special phenomenon, globalization has encouraged the flexibility and freedom of movement of people, money and information, ideas and knowledge; it also led, with the help of legal translation, to a decline of the geographical boundaries and achieved desires in resorting to legal or judicial systems of certain countries. Moreover, it has impacted criminal's abnormal thinking and behavior, and this was reflected in the expansion of criminal acts by using the technical and communication revolution, which contributed to the globalization of crimes and thus the emergence of the universal crimes or what are known as the 
cyber-crimes.

On the one hand, the efforts of combating a global crime became as one of the most important challenges faced by countries. As criminals have utilized the new development in technology, sciences, informatics and economy for commission new types of crimes within few minutes and from far distance, they use of international information and electronic media network, as in organized crime in general, whether economic, commercial or financial, became easy in speed and movement, precision in execution and obliteration of any material effect linking the crime, as well as the difficulty in determining the place of criminals and the location of their operations, as the purpose of committing this kind of crime goes beyond the traditional desire for material gain to what is beyond that where the target sometimes compromising the political side of the state or the erosion of its national or economic security.

On the other hand, recognizing the validity of the criminal law application is a manifestation of state sovereignty over its territory, and thus clear to us the right of the state in punishment violates the penal laws, but national criminal laws lose their relevance in the case of organized transnational crime, criminal activities may go beyond the borders of the state, but national laws have not such capacity, as it is supposed not to dispute in its essence with the commitments made by the state in the term of international legal principles, so it is important that legislative bodies have to review its criminal laws objectivity to detect weaknesses and make the necessary amendments in order to keep pace with these laws the evolution of new developed means used for commission of crimes .

The importance of legal translation in the age of globalization emerged in term of overcoming the "failure" of national criminal laws; it helps states to enter into bilateral agreements with other countries to develop its legal and judicial security. Hence, legal translation empowered states to keep some sorts of unified regulations govern the relationship of control and cooperation among them, as well as guided such states as provided by some regional conventions of international legal and procedural standards on combating certain crimes. Some examples of such unified conventions are the Council of Europe Convention on Cyber crime, International Instruments Dealing with Organized Criminal Matters by Members of the International Community, International Convention for the suppression of the Financing of Terrorism (1999), and the United Nations Convention against Transnational Organized Crime (border) National (2000), and the United Nations Convention against Corruption (2003), etc.

At present, there is a clear gape between the techniques of committing organized crimes and the legal mechanism for its control, where the globalization of crimes requires an affective control mechanism, therefore there some need to globalize the criminal laws of states of both legal systems of common law and continental school by relying on the efforts of legal translators as well as enhancing the reception of laws with aim of creating a universal international criminal law. Compacting of organized crimes require also rehabilitation and continuous training of the agents of criminal justice system in order to equip them with the technical possibilities for the detection of crime, as well as to enhance the legal and judicial cooperation in criminal matters among nations in criminal matters including organized crimes.

\section{REFERENCES}

[1] J. A. Scholte. (2002). What Is Globalization? The Definitional Issue Again. Centre for the Study of Globalization and Regionalization (CSGR), University of Warwick. [Online]. p. 4. Available: http://www.csgr.org

[2] N. R. F. A. Rodhan. (2006). Definitions of Globalization: A Comprehensive Overview and a Proposed Definition. Geneva Center for Security Policy. [Online]. p. 3. Available: http://www.gcsp.ch

[3] P. G. Cerny, "Globalization and the changing logic of collective action," International Organization, vol. 49, p. 596, 1995.

[4] T. C. Halliday and P. Osinsky, "Globalization of law," Annual Review of Sociology, vol. 32, p. 470, August 2006

[5] Alistair King. (2014). Legal Globalization: Investigating the Effects of an Inexorable Phenomenon. [Online]. p. 24. Available: http://www.justis.com/news/news-legal-globalization.pdf

[6] L. G. Pierrick, "Global law: A legal phenomenon emerging from the process of globalization," Indiana Journal of Global Legal Studies, vol. 14 , no. 1 , p. 127,2007

[7] C. H. Chan, "Legal globalization and law drafting and translation: Use of legal terms and technical words in intellectual property laws of the people's republic of China," Translation Quarterly, 2010, issue 58, p. 1, December 2010

[8] D. Cao, Translating Law, Multilingual Matters Ltd, Clevedon: U.K, 2007, p. 2

[9] Nigel Bankes. (2013). Legal Systems, Arctic Human Development Report. [Online]. p. 3. Available: http://www. svs.is/ahdr/ahdr

[10] M. S. McDougal, "The impact of international law upon national law: A policy-oriented perspective," South Dakota Law Review, vol. 4, pp. 25-92, 1959

[11] R. L. Arcas, "The reception of european community law in Spain," Hanse Law Review, HanseLR, vol. 1, no. 1, pp. 18-21, 2005.

[12] R. S. A. Faqir, "Protection the accused rights in Jordan and India: A comparative study," Ph.D Thesis, Faculty of Law, Delhi University, 2004

[13] B. Spinoza, Ethics, London, England: Penguin Classics, 2004.

[14] H. C. Faustino, A. C. Kaizeler, and R. J. Marques, "The ethics of a globalized world: A universal ethic?" Working Papers Submitted to Research Centre in Economic Sociology and the Sociology of Organizations, Technical University of Lisbon, Portugal, pp. 17-19, 2009.

[15] W. Twining, "Responding to globalization," OSGOODE Hall Law Journal, vol. 49, p. 363, 2011

[16] R. Domingo, The New Global Law, Cambridge, UK: Cambridge University Press, 2010, p. 182.

[17] J. Crawford and S. Marks, "The global democracy deficit: an essay on international law and its limits," in Re-Imagining Political Community: Studies in Cosmopolitan Democracy, D. Archibugi, D. Held, and M. Koehler Eds., Cambridge: Polity Press, 1998.

[18] D. Held, Democracy and the Global Order: From the Modern State to Cosmopolitan Governance, Cambridge: Polity Press, 1995.

[19] Report on Globalization and Its Impact, International Labor Organization. [Online]. Available: http://www.ilo.org/public/english/wcsdg/docs/rep2.pdf

[20] P. Tappan, "Who is the criminal?" in What is Crime, S. Henry and M. Lanier Eds., New York: Rowman and Littlefield Publishers, inc., 2001.

[21] D. Garland, "The criminal and his science: A critical account of the formation of criminology at the end of the nineteenth century," The British Journal of Criminology, vol. 25, no. 2, 1985.

[22] U. Beck, Risk Society: Towards a New Modernity. London, Newbury Park, New Delhi: Sage, Theory, culture \& society, 1986.

[23] J. Charney, "Transnational corporations and developing public international law,” Duke Law Journal, pp. 748-749, 1983.

[24] A. G. Scherer and G. Palazzo, Handbook of Research on Global Corporate Citizenship, Edward Elgar, Cheltenham, 2008.

[25] United Nations Office on Drugs and Crime, The Globalization of Crime: A Transitional Organized Crime Threat Assessment, Vienna, 2010.

[26] S. A. Millan, J. E. Foltz, J. Jackson, and A. Oberg. (2008). Globalization of Crime, the Futurist. [Online]. Available: http://www.wfs.org 
[27] D. Nicola and A. Scartezzin, "When economic crime becomes organized: the role of information technologies, a case study," Journal of the Institute of Criminology, University of Sidney, Faculty of Law, vol. 11, no. 3, p. 1, March 2000.

[28] A. Bequai, How to Prevent Computer Crime: A Guide to Forensic and Technology, San Diego: Academic Press, 2002.

[29] E. Sutherland, White Collar Crime, New York: Dryden Press, 1949.

[30] A. Graycar, "New crimes or new response, paper presented at the 4th national outlook symposium on crime in Australia," New Crimes or New Responses convened by the Australian Institute of Criminology and held in Canberra, 21-22 June 2001

[31] M. Holvoet and P. de Hert, "International criminal law as global law: An assessment of the hybrid tribunals," Tilburg Law Review, vol. 17, pp. 228-240, 2012.

[32] J. Braithwaite, Inequality, Crime and Public Policy, London: Routledge and Kegan Paul, 1979.

[33] U. A. Karofi and J. Mwanza, "Globalisation and crime," Bangladesh e-Journal of Sociology, vol. 3, no. 1, January, pp. 1-20, 2006.

[34] G. P. Fletcher, "Parochial versus universal criminal law," Journal of International Criminal Justice, no. 3, p. 4, 2005.

[35] R. S. A. Faqir, "The criminal liability of state: Myanmar case, unpublished research," pp. 7-8, 2014

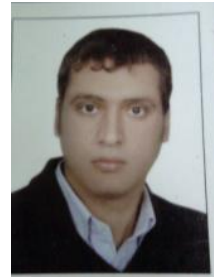

Morad Yasin Deab Al-Refo was born in Jordan, and he has received his degree of bachelor, master and doctor in translation and literature. He is a great poet and founder of peace cross-border movement, and is currently a faculty member at the Umm Al Qura University in Saudi Arabia. His areas of research interest include legal translation, international treaties and conventions, humanitarian linguistics, and peace studies.

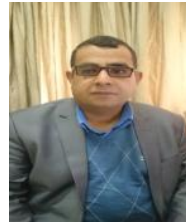

Raed S. A. Faqir holds a Ph.D. in comparative law from Delhi University. He serves as an associate professor of law and deputy dean at Al-Balqa Applied University and Zarqa University, Jordan. Before, he was practicing as an advocate in Jordanian courts from 2005 to 2006. He also worked as an officer to the Ministry of External Affairs of Jordan at the Jordanian Embassy in Delhi from 2000 to 2004. His teaching areas include criminal law, international law, human rights law, business law and management. He has published many articles, mainly on constitutional law reforms and legal mechanisms for combating corruption in Jordan and on human rights and the rights of minorities from the Jordanian perspective. Dr. Faqir recently joined the Department of Law at City University College of Ajman (CUCA), UAE. 